\title{
City Slums as a Recognition of Migrants' Rights
}

A Proposal from Qin Hui

\section{Edmund W. Cheng}

\section{(2) OpenEdition}

\section{Journals}

Electronic version

URL: http://journals.openedition.org/chinaperspectives/4747

DOI: 10.4000/chinaperspectives. 4747

ISSN: 1996-4617

\section{Publisher}

Centre d'étude français sur la Chine contemporaine

\section{Printed version}

Date of publication: 1 December 2008

Number of pages: 84-89

ISSN: 2070-3449

Electronic reference

Edmund W. Cheng, "City Slums as a Recognition of Migrants' Rights », China Perspectives [Online], 2008/4 | 2008, Online since 01 December 2011, connection on 15 September 2020. URL : http:// journals.openedition.org/chinaperspectives/4747 
C

City Slums as a Recognition

of Migrants' Rights

A Proposal from Qin Hui

EDMUND W. CHENG

$Q^{2}$ in Hui, an influential public intellectual and historian from Tsinghua University, proposes allowing the formation of slums (pinmin ku) to accommodate the millions of migrants in Chinese cities. ${ }^{(1)}$ This seemingly absurd suggestion has attracted much public attention and discussion. ${ }^{(2)}$ Slums are often regarded as a symbol of urban deterioration, a source of social problems, or even as one of the sins of capitalism. Chinese officials are very proud that the rapid economic development of the past three decades has not produced the types of problems that can be found in other developing countries. However, Qin insists that the absence of slums is even worse than their presence. ${ }^{(3)}$ Chinese cities have been exempted from this natural phenomenon, which usually accompanies rapid urbanisation, simply because government policy has prohibited slums from emerging.

Using the Haussmannisation of Paris and apartheid in South Africa as analogies, Qin explores the institutional discrimination against Chinese migrants, and advocates the recognition of migrants' rights to end this injustice. This rights-based perspective is in contrast to the utilitarian-based state policy that treats migrants as a necessary yet alienated labour force. Provoking this tension in the political spectrum, Qin's proposal dragged people of different positions, willing or not, into the deliberation on migrants' rights.

\section{Rapid urbanisation under the hukou system}

The entrenched polarisation associated with the "opening and reform" (gaige kaifang) policy that liberalised the labour force and the household registration (hukou) system that constrained rural-urban migration are the sources of Qin's concern. On the one hand, the economic reforms of the past three decades have led to rapid urbanisation in China. The country's urban population increased from 18 percent of the total in 1978 to 44 percent in 2006. ${ }^{(4)}$ Urban incomes rose

from 2.57 to 3.27 times those of rural incomes in the same period. ${ }^{(5)}$ This discrepancy in pay has motivated the rural population to enter urban areas in search of better job opportunities. On the other hand, the rights and social benefits of this population are constrained by another policy that was enacted in 1958-the hukou system. According to this system, individuals are assigned to either an urban or rural household based on their place of residence. The provision of social benefits, such as education, housing, and health care, is restricted to the relevant hukou type. The approval of the authorities is needed if a member of the rural population wants to move to the city. When such people leave their county to work in the city, however, they forfeit their rights and benefits. Local governments are not obliged to take any responsibility or provide any services beyond an individual's household jurisdiction. ${ }^{(6)}$

This policy is meant to ensure efficient resource allocation, the monitoring of criminals, and structural stability, but migrants have gradually become targets of daily exploitation and social discrimination. ${ }^{(7)}$ The system has served to insti-

1. Qin Hui, "Urbanisation and the rights of migrants: Changing community conditions of the lower class in modern worlds," Southern Metropolitan Daily, 13 April 2008, p. A1; Qin Hui, "South Africa's Soweto phenomenon: The past and the present," Southern Metropolitan Daily, 2 May 2008, p. A30; Qin Hui, "Once again on South Africa: A mirror of institutional discrimination," Southern Metropolitan Daily, 6 June 2008, p. A4; Qin Hui, "Residential rights before welfare improvements," Southern Metropolitan Daily, 15 June 2008, p. A7.

2. More than 90 articles, reports, and analyses were devoted to the topic from April to June 2008, including three subsequent articles written by Qin Hui in response to his critics. Retrieved from WiseNews: http://wisenews.wisers.net/wisenews.

3. Qin, "Urbanisation and the rights of migrants: Changing community conditions of the lower class in modern worlds," op. cit.

4. Xinhua News Agency, quoting the National Bureau of Statistics, 22 October 2007.

5. Zhu Qingfang, "A comprehensive target system revaluation of harmonious development in an economic society," in Tuo Xin, Lu Xueyi, and Li Peilin (eds), 2007: An Analysis and Forecast of Trends in Chinese Society, Beijing, China Social Sciences Press, 2006, pp. 321-339.

6. Congressional Executive Commission on China (CECC), "China Household Registration System," 7 October 2005; China Labour Bulletin (CLB), "Migrant Workers in China," 6 June 2008.

7. Fei Ling Wang, Organizing Through Division and Exclusion, Stanford: Stanford University Press, 2005. 
tutionalise the country's 130 million migrants as second-class citizens. The problem has intensified with changing norms regarding these migrants' residence in urban areas. In Shanghai, for instance, the percentage of migrants staying in the city for more than five years increased from 6.3 percent in 1993 to 24.3 percent in 2003, and whole family migration is also expected to increase. ${ }^{(8)}$ Such figures belie the suspicion that migrant workers may not have the incentive to settle in a city permanently. Therefore, the provision of suitable housing for these workers is imperative and pressing.

\section{Chinese Haussmannisation} and rights

Qin insists that the current practice goes beyond the "humanitarian bottom-line," as migrants are denied the basic right to become a genuine part of the city. ${ }^{(9)}$ Citizens in any modern democratic society either enjoy the liberty to live in slums, or the state provides adequate welfare benefits to eliminate them, or a balance is struck between the two. However, migrants in China are neither entitled to settle down in slums, nor given welfare benefits to help them avoid doing so. ${ }^{(1)}$ They have become an abandoned population whose premier function is to serve as a cheap labour force in developed urban areas. They are allowed to stay in temporary residences provided by their employers or local landlords on the conditions that they are employed and regularly registered with the public security forces. ${ }^{\text {(II) }}$ They are not qualified to gain residency status and are expected to return to their home county after a period of prolonged unemployment or at retirement-normally after the age of 35. ${ }^{(12)}$ Local authorities are eager to clear out migrants when their capacity to serve in the city approaches zero. ${ }^{(13)}$ Qin describes all these measures as a result of "Chinese Haussmannisation" - a management principle aimed at progressive urban modernisation, which in turn leads to widespread grievance among the floating migrants. ${ }^{(14)}$

Haussmannisation is named for Baron Haussmann, who was the civic planner responsible for bringing order and structure to the overcrowded and cramped conditions of Paris during the Industrial Revolution. Reconstruction started in 1853 - two years after the Second French Republic became the Second French Empire under Napoleon III. The emperor had complete control of the country and was eager to spend money to make Paris the model of modernity. ${ }^{(15)}$ It is estimated that the total cost of the renovation was 2.5 billion francs, 44 times the annual budget of France in 1851. ${ }^{(16)}$ Money and power made Haussmann's renovation a remarkable success that espoused the axioms of modernity, progress, and the public interest. ${ }^{(17)}$ Such a project incorporates the concept of modernity into the public discourse through the transformation of physical urban structures. ${ }^{(18)}$ As Haussmann wrote:

These underground galleries [water and sewage pipes] would be the organs of the metropolis and function like those of the human body without ever seeing the light of day. Pure and fresh water, along with light and heat, would circulate like diverse fluids whose movement and replenishment sustain life itself. These liquids would work unseen and maintain public health without disrupting the smooth running of the city and without spoiling its exterior beauty. ${ }^{(19)}$

The metaphor of the body and urbanisation taught the public to distinguish beauty from the beast and to learn what is legitimate to be seen and what has to be hidden, and ensured the triumph of modernity. In Qin's view, Haussmann's Paris was a "beauty manifestation" of an authoritarian regime that denied the residential and civic rights of the underprivileged. Not only were ordinary citizens detached from one another based on geographical distance and psychological impulse, but the reconstruction also granted more living space, grand architecture, and pride to the privileged in the name of the public interest. ${ }^{(2)}$ Most importantly, it set a precedent for and legitimated all forms of catastrophic management by the city thereafter.

8. Yuen Ren, "Gradually settling down and the decision to settle down depends on the right of abode," Population Science of China, 3, 2006, pp. 67-96.

9. Qin, "Urbanisation and the rights of migrants: Changing community conditions of the lower class in modern worlds,"op. cit.

10. Ibid.

11. CLB, op. cit.

12. Ibid.

13. Ibid.

14. Qin, "Urbanisation and the rights of migrants: Changing community conditions of the lower class in modern worlds," op. cit.

15. Anthony Sutcliffe, Paris: An Architectural History. New Haven, Yale University Press, 1993.

16. David H. Pickney, "Money and Politics in the Rebuilding of Paris, 1860-1870," The Journal of Economic History 17(1), 1957, pp. 45-61.

17. L. Benevolo, The European City, Oxford, Blackwell, 1993; D.P. Jordon, Transforming Paris: the Life and Labours of Baron Haussmann, New York, Free Press, 1995.

18. Matthew Gandy, "The Paris Sewers and the Rationalization of Urban Space," Transactions of the Institute of British Geographers, 24(1), 1999, pp. 23-24.

19. Baron Haussmann, Mémoire sur les eaux de Paris présenté à la Commission Municipale par M. le Préfet de la Seine Vinchon. Paris, 1854, p. 53. Quoted from Gandy, op. cit., p. 24.

20. Qin, "Urbanisation and the rights of migrants: Changing community conditions of the lower class in modern worlds," op. cit. 
Indeed, similar scenarios have occurred, with similar justifications given, in contemporary China. Rural lands are annexed and old buildings are dismantled in the process of modernising the city. Whilst the majority of the land acquired is used for private property construction and commercial and manufacturing uses, a significant portion is retained for public fringe benefits. The criterion for accessing these benefits, however, is based on the hierarchy of officialdom or the wealth of the state-owned enterprise, not on the need to provide basic shelter to the poor. According to a report in China Newsweek, middle-ranked officials in Xinyang City in Henan Province occupy villas that average $250 \mathrm{~m} 2$ in size, which they obtained through internal allocation; ${ }^{(21)}$ at the same time, the average living space of migrant workers in Shanghai is $6 \mathrm{~m}^{2}$, less than one-fortieth of that size. ${ }^{(22)} \mathrm{To}$ Qin, this is an absurd policy that means "the richest have replaced the poorest in obtaining public housing in China."

The formation of socialised discrimination against the lower class is perhaps even more striking than this institutional suppression. There have been repeated reports of taxi drivers refusing to allow migrants into their vehicles. ${ }^{(23)}$ Under the impression that these people may not have the money to pay the fare or worrying that their dirt will adhere to the seats, which will in turn lead to a penalty during regular traffic inspections, numerous taxi drivers simply turn a blind eye to injured or pregnant migrants who are in desperate need of their services. ${ }^{(24)}$ These actions have been spontaneous, collective, and legitimated among taxi drivers across time and space in Chinese cities. The structural cause is that migrants are viewed with prejudice and seen as dirty, destitute, savage, and servile - the enemies of the modern city. Although the earning capacity of taxi drivers may be higher than that of migrants, their origins, ambitions, and job nature put them into a similar social stratum. This discrimination is therefore not entirely about class cleavage; rather, it is a socialised confrontation between rural and urban identity.

Discrimination against migrants as alleged sources of social problems or even as pollutants of the city is not going to bring a progressive and modern city, however. Qin insists that the achievements of Haussmannisation in Paris have been exaggerated, while its drawbacks have never been fully addressed. A lot of effort, including the provision of public housing and more responsive governance, was expended in the post-Haussmann era to alleviate the social tensions generated by the reconstruction. Recent research has also proved that Paris's modernised water supply and sewage system - a crux of Haussmannisation - was not accomplished until the 1890s. ${ }^{(25)}$ During this period of time, Paris also suf- fered from the continuous threat of cholera beneath the veneer of a modern hygienic city. ${ }^{(26)}$ In other words, if Chinese civic planners mistakenly treat Haussmannisation as the default path to the modernised city, then they are not only guilty of a conceptual fallacy, but they may also trigger the severe social discontent that occurred in the late Second French Empire.

\section{China's apartheid and welfare}

Besides Haussmannisation, apartheid is another analogy raised by Qin to reflect the injustice against migrants. The term "China's apartheid" is used by scholars to describe how China's hukou system has divided the population into two distinct groups, urban and rural. ${ }^{(27)}$ While not making explicit reference to the hukou system as "China's apartheid," Qin addresses South Africa's Soweto as a "mirror" of institutional discrimination in China. ${ }^{(28)} \mathrm{He}$ offers the dynamic transformation of Soweto to justify the benefits of slums in Chinese cities. Not only would they encourage the provision of welfare benefits to migrants, they would also enable the organic flourishing of the group as a socio-political entity. ${ }^{(29)}$ Before the termination of apartheid in South Africa, Johannesburg was a peaceful and organised city that was reserved for whites. Blacks were denied entrance to the city and enjoyed social, economic, and political rights that were largely inferior to those of whites. ${ }^{(30)}$ Rapid economic development and urbanisation after WWII, however, led to increased demand for workers in labour-intensive, low-skilled jobs that educated whites were unwilling to take, and the burden was placed on blacks. The government authorities enclosed a sub-rural area southwest of Johannesburg to enable blacks to

21. China Newsweek, vol. 381, 28 July 2008, pp. 24-36.

22. State Council, Research Report on Chinese Migrant Workers, Shiyan Chubanshe, 2006, p. 276.

23. See, for instance, Ming Pao, 5 January 2006, p. A27; Southern Metropolitan Daily, 2 May 2007, p. A18; The Beijing News, 19 August 2007, p. A20; Qilu Evening News, 17 March 2008, p. A10.

24. Ibid.

25. M. Gandy, op. cit., pp. 22-44

26. C J. Kudlick, Cholera in Post-revolutionary Paris: A Cultural History, Berkeley, University of California Press, 1996.

27. Anita Chan and Robert A. Senser, "China's Troubled Workers," Foreign Affairs, March/April 1997.

28. Qin, "South Africa's Soweto phenomenon: The past and the present," "Once again on South Africa: A mirror of institutional discrimination," op. cit.

29. Ibid.

30. Susan Parnell, "State Intervention in Housing Provision in the 1980s," in David M. Smith (ed.), The Apartheid City and Beyond: Urbanization and Social Change in South Africa, New York, Routledge. 1992, pp. 53-64. 
serve white citizens effectively and efficiently. The area originally referred to as the South Western Township was abbreviated Soweto in the 1960s and gradually developed into an area that housed 1.6 million people by the 1980s. ${ }^{(31)}$ Qin states: "If Johannesburg is . . Paradise; Soweto is ... Hell." However, he also notes that the existence of a communal network and a responsive and representative government has in recent years led to many improvements in Soweto that have significantly altered the situation. ${ }^{(2)}$

For instance, the largest bus station in Africa is now situated in Soweto. At Christmas time, hundreds and thousands of workers stream into this station looking for a ticket home. The situation is very similar to what occurs in China before the Lunar New Year, when migrants rush back to their home counties. However, although the phenomenon is similar, the composition of the migrants leaving Soweto is different from that in China. Most of them are actually foreign workers from Botswana, Mozambique, Swaziland, and Zimbabwe rather than South African citizens. ${ }^{(33)}$ Since the abolition of apartheid, South African nationals working in the area have their own houses, albeit crowded and cramped ones, in Soweto or Johannesburg. ${ }^{\left({ }^{4}\right)}$ Thus, they no longer have the problem of going home (huijia), because their homes are where they live and work. The huijia issue is one that troubles nearly every Chinese migrant, and one that would be resolved for their families and local authorities if they were given the opportunity to form their own communities.

It seems that Qin is making the claim that the transformation of Soweto is not a direct result of the abolition of apartheid. Instead, the existence of a living space devoted solely to the black community - serving, inspiring, and unifying it - contributed dynamically to the anti-apartheid movement. Since 1994, blacks have enjoyed equal citizenship rights to whites, and slums can now be built in both Soweto and Johannesburg. Studies have shown, however, that the separate squatter areas and slums that emerged in the 1960s became breeding grounds for anti-apartheid leaders such as Archbishop Desmond Tutu. ${ }^{(35)}$ They gave blacks the opportunity to identify with their locality, to become visible to the nation and to the world, and to become recognised as an exploited group. The National Party of South Africa intended to eliminate Soweto, as they had done to the Western Township, to cover up the troubles, but this led to severe resistance. ${ }^{(36)}$ Given the South African experience, the underlying question is whether the restriction of slums is more justified than their formation. For Qin, only an exposed and visible grievance, not a cover-up, can provoke recognition of migrants' rights. ${ }^{(37)}$

\section{The deniers, the sceptics, the idealists, and the politics of recognition}

Qin's proposal has aroused intense and diverse debate. Public opinion, as expressed in a number of newspaper articles, is overwhelmingly positive towards the formation of slums as a legitimate way to guarantee migrants' rights and welfare (quanli); to enable the floating population to settle down (anshen); to promote the assimilation (ronghe) of the rural and urban populations; and to show humanitarian concern towards the exploited. ${ }^{(38)}$ Despite their different perspectives, all of these writers share the view that the current situation is intolerable; action, rather than patience, is needed. ${ }^{(39)}$ Three types of counter responses have also been documented, however, each with a different socio-political orientation.

The first group is composed of deniers who represent the official view or insist on the improvement of migrants' rights. For this group, the creation of slums is either a lazy or crazy idea that refuses to consider the crisis realistically. ${ }^{(40)} \mathrm{Qi} \mathrm{Ji}$, a deputy minister of the Ministry of Housing and UrbanRural Development, denies any possibility of allowing slums. $\mathrm{He}$ insists it is the government's policy to resolve the housing problem step by step. This means first allocating resources to urban households, then extending them to permanent residents, ultimately including the floating population if resources permit. ${ }^{(41)}$

Undoubtedly, some promising measures have been taken, such as the education of migrants' children, addressing

31. Dhiru, V. Soni, "The Apartheid State and Black Housing Struggle," David M. Smith (ed.) The Apartheid City and Beyond: Urbanization and Social Change in South Africa, New York, Routledge, 1992, pp. 39-52.

32. Qin, "South Africa's Soweto phenomenon: The past and the present," "Once again on South Africa: A mirror of institutional discrimination,"op. cit.

33. Ibid

34. Ibid.

35. David M. Smith (ed.), The Apartheid City and Beyond: Urbanization and Social Change in South Africa, New York, Routledge, 1992.

36. Ibid.

37. Qin, "South Africa's Soweto phenomenon: The past and the present," "Once again on South Africa: A mirror of institutional discrimination," op. cit.

38. For instance, Shu Shengxiang, "The value of slums is to protect basic liberty," Chuncheng Evening News, 15 April 2008, p. A3; Ju Fangye, "Construction of slums is not a shame for cities," Quli Evening News, 15 April 2008, p. A2; Tong Dahaun, "Is a slum a flood or a monster?" Oriental Morning Post, 22 April 2008, p. A23; Gu Zechu, "Who has slums; who will have prosperity?" Southern Metropolitan Daily, 21 April 2008, p. A23.

39. Ibid.

40. Guo Songmin, "Building slums is an absolutely crazy idea," Guangzhou Daily, 15 April 2008, p. A15; Zhang Junyu, "Constructing slums is a lazy idea from a lazy man," Zhang Sha Evening News, 17 April 2008, p. A9.

41. The Beijing News, 17 April 2008, A17. 
abuse of migrants, and the provision of emergency medical services. However, the announcement by the Beijing municipality of its intention to eliminate the distinction between agricultural and non-agricultural hukou status may give rise to unrealistic expectations. ${ }^{\left({ }^{(2)}\right)}$ Similar changes have occurred in the other 12 provinces, but none of them has abolished hukou identification entirely. The registration requirement for permanent residency remains intact, and migrants still have to satisfy the criteria set by local authorities to obtain a local hukou and thus enjoy social security benefits. ${ }^{(43)}$ For instance, the annual minimum wage in urban Beijing is 4,680 Yuan, whereas that for rural Beijing areas is 1,780 Yuan. ${ }^{(44)}$ Indeed, the current hukou reform is an extension of the State Council reform of 1997, which allowed the transfer of hukou from a rural to an urban area provided that the migrant has 1) a stable source of income and 2) a stable place of residence. In addition, the applicant has to 3) work in a secondary or tertiary industry, 4) work in management or professional services, and 5) own an apartment. This practice was extended to all towns and cities in 2001. ${ }^{(4)}$

Because this executive ordinance fails to define a stable income or specify the value of the property that must be owned, local authorities are given the discretion to set respective limits. In Wuxi, for instance, to obtain an urban hukou an applicant must own a $100 \mathrm{~m}^{2}$ apartment, have paid 10,000 Yuan in taxes for two consecutive years, or be employed in a profession that is urgently needed by the city. ${ }^{(46)}$ These requirements are far beyond the capacity of the majority of migrants. For example, only 2 percent of the 2 million migrants in Ningbo - one of the wealthiest cities in China and a model for hukou reform - have successfully transferred to an urban hukou. ${ }^{(47)}$ As an article from China Labour Bulletin states, "instead of granting citizens the right to internal migration, in effect, the policy was more of an immigration scheme to attract investment and talent." ${ }^{(48)}$ The deniers' hasty or deliberate focus on the word "slum" has allowed them to overlook its inherent rights-based inference. The criterion for judgment is always how much is given by the government, but never on whether migrants should be entitled to particular rights in the first place.

The second group of critics, although agreeing with the appropriateness of Qin's concerns, remains sceptical about the feasibility of allowing the formation of slums. These commentators worry that it would have the effect of labelling migrants and thus further intensify the division between the haves and the have-nots. ${ }^{(4)}$ Due to migrants' economic limitations and the scarcity of urban resources, they predict that slums would tend to be located in suburbs without a sustainable threshold of public services or sufficient job opportunities. They note that some migrant workers in Guangzhou have abandoned the squatter areas and low-rent housing (lian zufang) provided by local authorities because of the high travelling costs and the dangerous neighbourhoods in which they are located. ${ }^{(50)}$ In the long run, they say, migrants and more particularly their offspring would be stuck in the slum and feel ashamed of their identity. ${ }^{\left({ }^{11)}\right.}$

Although these critics make quite general assertions, their worries are not totally unjustified. Qin from the beginning foresaw the possibility of slum deterioration and the way local authorities would deal with it. Numerous urban villages (chengzhongcun) have actually formed in the city centres of Beijing, Shanghai, Guangzhou, and Shenzhen. Functionally, they are identical to slums in their provision of affordable shelter and primitive services to migrants. ${ }^{(52)}$ These chengzhongcun, however, are often regarded as sources of crime, crowding, and poverty by urban citizens; thus, local authorities have the motivation to clean them up, as they can then take credit for making progress. Very few of them have considered that urbanisation, poverty, and crowding may have caused chengzhongcun, rather than resulted from them. Without a formal recognition of migrants' rights, it is difficult to reverse such orthodox thinking from the public discourse. This explains why Qin, while not indicating who should lead the construction of migrant housing, frequently stresses the responsibility of government to offer welfare provisions for all inhabitants. A transformative reform put forward by the state centre is still the best available safeguard against future local policy reversal.

42. Xinhua News Agency, 31 December 2008.

43. CECC, op. cit.

44. Beijing Commercial Daily, 31 December 2008, p. 1.

45. "State Council notice on approving the Public Security Bureau's opinions on promoting reform on the management of household registration system in small towns and cities," issued 30 March 2001.

46. Wuxi City Government Notice of Issuance of the City Public Security Bureau's "Instruction to obtain a local Hukou." Retrieved on 16 January 2008.

47. Southern Weekly, 31 August 2001.

48. CLB, op. cit.

49. Chen Yizhou, "Segregation of the rich from the poor should not be the price for projecting the rights of the underprivileged," Southern Metropolitan Daily, 14 April 2008, p. A2; Bige, "Construction of slums might lead to more dualistic separation," Chun Cheng Evening News, p. A3; Wang Jiafeng "What kind of residences do urban migrant workers need?" Jie Fang Daily, 22 April 2008, p. 7.

50. Bige, op. cit.

51. Chen Yizhou, op. cit.

52. L. Zhang and S. Zhao, "Self-help in Housing and Urban Villages in China's Urbanization," International Journal of Urban and Regional Research, 27(4), 2003, pp. 912-937. 
Idealists make up the third group. Admittedly, these critics include those who are concerned with the well-being of migrants and those who believe that liberty, fairness, and democracy should be the criteria for evaluating and recommending policy. At the same time, however, they believe that little can be done under the current socio-political structure. Their perspective can be summed up by the title of an article by one of these respondents, Tao Duanfang: "Advancing 100 steps or 50 steps is not a matter of substantial difference." ${ }^{(3)}$ Tao uses the insignificant distinction between born slaves and contract slaves as an analogy to show that the creation of slums is an eclectic process that does not exempt migrants from institutional and societal discrimination. If there is only a minimal provision of goods and services in periphery and state-initiated squatter areas, then this might actually reinforce the exploitative relationship without providing any possibility for the long-term development of migrants. In Qin's view, however, the dynamic development of Soweto justifies an optimistic view of slum creation. The existence of slums would enable the political recognition of migrants as an inalienable part of the Chinese city and the Chinese population. Hence, the divergence between the opinions of Qin and those of the idealists is not whether migrants are entitled to basic civic and political rights; it is whether these rights should be complemented by welfare provisions and a decent standard of living. Qin calls for dynamic development towards an end, whereas the idealists call for the immediate arrival of that end.

Contrary to the deniers who are merely spokesmen of the administration, Qin does not believe that rights are granted by the state. But he seems convinced that the state, rather than the market or civil society, is a more suitable policy initiator for slum formation. At the same time, he does not share the view of some of the sceptics who advocate a sort of communitarian affirmative action for migrants. Rather, he aims at universal equal treatment for the rural and urban populations. Nonetheless, the universal concern does not make him an authentic liberal or idealist. For Qin, rights are neither a natural entitlement nor a mere contractual provision. ${ }^{(54)}$

All in all, Qin is a historian and a social activist. As a historian, he emphasises the complexity of acquiring rights and the difficulty in gaining recognition for them. Therefore, the dynamic struggle of Soweto is used to demonstrate the merits of having an inspirational, provocative, and visible physical structure for the disadvantaged. Allowing the formation of slums in China is aimed at delivering an endowment for future socio-political recognition and welfare delivery for mi- grants. As a social activist, he knows how to set an agenda for deliberation. By choosing the slum - a seemly negative word - he has challenged the "progressive" discourse associated with Haussmannisation. Availing at the critical moment when a new wave of rural-urban migration is about to be triggered by the recent Land Reform (diquan gaige), under which peasants are entitled to transfer their land rights to any party, his notion, even if it does not entail immediate policy implication, has set the context for deliberation on migrants' rights in the public discourse.

$\begin{array}{ll}\text { Glossary } & \\ \text { Qin Hui } & \text { 秦暉 } \\ \text { pinmin ku } & \text { 貧民窟 } \\ \text { gaige kaifang } & \text { 改革開放 } \\ \text { hukou } & \text { 户口 } \\ \text { Xinyang } & \text { 信陽 } \\ \text { huijia } & \text { 回家 } \\ \text { quanli } & \text { 權利 } \\ \text { anshen } & \text { 安身 } \\ \text { ronghe } & \text { 融合 } \\ \text { Wuxi } & \text { 無錫 } \\ \text { Ningbo } & \text { 寧波 } \\ \text { chengzhongcun } & \text { 城中村 } \\ \text { Tao Duanfang } & \text { 陶短房 } \\ \text { diquan gaige } & \text { 地權改革 }\end{array}$

53. Tao Duanfang, "Constructing slums is respecting freedom?" The Beijing News, 17 April 2008, p. A4; Tao Duanfang, "Advancing 100 steps or 50 steps is not a matter of substantial difference," Southern Metropolitan Daily, 5 May 2008, p. A23.

54. Qin, "Residential rights before welfare improvements," op. cit. 